\title{
Recruiting students to campus Creating tangible and digital products in the academic library
}

$\mathbf{F}_{\mathrm{o}}^{\circ}$ orget about databases, e-resources, and comfy seating. Instead, create something with prospective students visiting your academic library.

Let us clarify. While traditional tours discussing library resources and study spaces might be tempting to discuss during an introductory campus visit, quite frankly, few prospective students care. ${ }^{1}$ Students assume that the resources they need for class, studying, and research will be available to them one way or another. Save the specific lectures on library resources for after they decide to attend your institution, ${ }^{2}$ and, during their initial visit, do something fun with them-create!

Academic library involvement in campus recruiting has only recently been discussed in the scholarly literature. The first report appeared in 2007, and since then, there have only been a handful of articles in the library literature discussing student recruitment. ${ }^{3,4}$ Libraries' participation in college recruitment has largely focused on traditional approaches, such as general tours, information fairs, workshops, and distribution of advertising materials

A few libraries have started to enhance student recruitment efforts. For example, Miami University Libraries has incorporated anecdotal storytelling within its tours, and Brigham Young University Libraries leveraged its special collections to create a series of exciting and targeted presentations within the recruitment tour. ${ }^{5,6}$

\section{Our take on student recruitment}

Over the past several years at the University of Alabama (UA) Libraries, we partnered with the UA Office of Orientation and Special Programs to provide a library activity within its Sibling Orientation program. Sibling Orientation is a summer recruiting program for high school siblings of entering freshman undergraduate students.

Like many programs, the Sibling Orientation program has changed and grown over time. During the first few years, the program was a one-day event, but now it has expanded to a two-day program. The agenda includes multiple tours and discussions around campus, including activities such as meeting current UA students, discussing academics and campus life, touring athletic facilities, and participating in an activity within the library. Groups of prospective students are led to each stop on the orientation tour by a UA Avanti Orientation Team member. The Avanti Team is a UA student service organization that helps new UA students succeed in higher education.

The Sanford Media Center (SMC), our in-house library digital media student space, was initially contacted about being part of the program because a number of the stu-

Vincent F. Scalfani is science and engineering librarian, email: vfscalfani@ua.edu, and Lindley C. Shedd is associate professor and media services coordinator, Sanford Media Center, at the University of Alabama Libraries, email: Icshedd@ua.edu

๑) 2015 Vincent F. Scalfani and Lindley C. Shedd 
dent orientation leaders (the Avantis) were active SMC users and thought that the media center counted as one of "cool places" on campus. The Sibling Orientation program is designed to show students the fun side of campus. Our goal for the library part of program was to introduce students to the libraries in an active way, while showing them a different kind of library service. UA Libraries has participated in approximately 15 sessions of Sibling Orientation annually since 2008. The program first began as a collaboration between the UA Libraries' SMC and the UA Office of Orientation and Special Programs.

As Sibling Orientation evolved over the years, our libraries acquired many new technologies. As

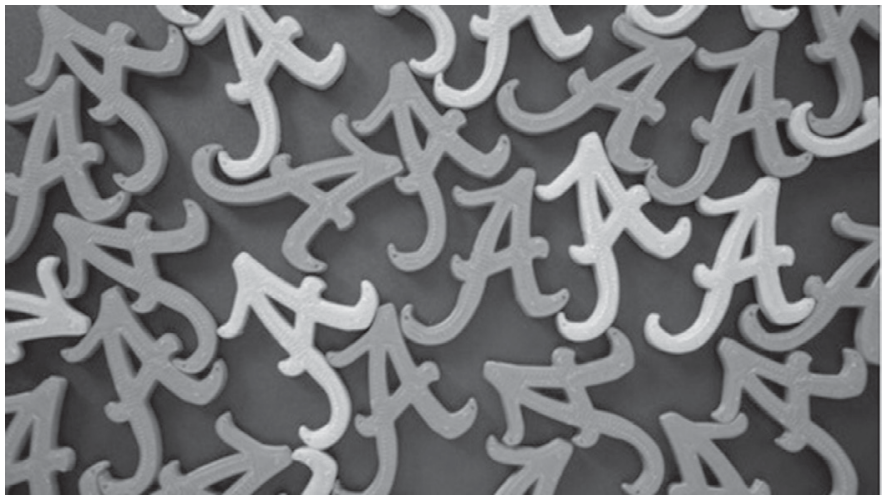

was able to choose the media content to include in his or her video. After editing and compiling the videos, students copied their unique video to a disc, which they could then take home.

In the latest iteration of Sibling Orientation, participants were guided through two main activities in the libraries: 1) in the UA Libraries 3-D Studio, the Science and Engineering librarian created 3-D printed Alabama script A logos with the students (see image below), and 2) in the Sanford Media Center, the media services coordinator continued

such, these 3-D printed Alabama script A logos that were created during a pronew tech- spective student library tour.

nologies were incorporated within the Sibling Orientation library activity.

During the first few years of the program, the media center portion focused on students creating composite images in Photoshop, but as participants' were being exposed to more technology during high school, we had to find new ways to keep them engaged.

In 2011, the SMC project morphed to guiding prospective students through the creation of a one-minute video of their individual experiences throughout the twoday orientation. We used Apple iMovie to create the videos with students, as iMovie is a simple introductory video editing program that does not have a steep learning curve.

The student videos incorporated pictures that students took throughout their tour of UA and also various stock video footage we provided from the libraries. Each student to offer the media project based on the images and video from their visit. $\mathrm{P}$ r $\mathrm{O}$ spective students learned a variety of skills by working directly with librarians, such as how to start a 3-D print, basic photography editing, and short clip video editing. Each student left the UA campus with a tangible 3-D printed Alabama script A object and a digital copy of his or her unique orientation video.

\section{What we learned}

Overall, our participation in the UA Sibling Orientation was a great success. Feedback and interest from the prospective students was very positive, and they were lively and engaged in the library activities. We were excited to be able to work with students and create both a tangible and digital product with them. However, we discovered several limitations and challenges with our participation in the activity that are outlined below:

- Time allotment. Our Sibling Orientation library activity was limited to about one hour with the prospective students. 
With only an hour to edit a video and start a 3-D print job, there was not much time for questions, informal discussions, or to provide individual help to prospective students. Moreover, 3-D printing can be a slow process that can take several hours just to complete a single print. To ensure that every student received a 3-D printed Alabama script A, it was necessary to print many of the script A's ahead of time, which led to less hands-on time for the students. If your time is limited, offer multiple library activities, but then let students choose one activity they would like to participate in. After completing the activity, students could then be re-grouped together to discuss and share what they learned about their chosen activity.

- Avanti tour guide training. We found it critical to train the Avanti tour guides with the library technology used in the activities. The Avantis were then able to participate in the activity and offer assistance to prospective students. Engaged, knowledgeable, and lively, the Avantis made a huge difference in student participation and overall outcome of the activity. We recommend holding a training session for any assistants who will be present during your orientation activity.

- Scalability. As the Sibling Orientation program grew in popularity, scalability became a challenge. Not only were there many more sessions, but the number of students in each session became more than we could comfortably accommodate within our Libraries Media Center. This forced us to reserve a computer room in an academic building outside of the libraries. As a result, it is likely that some of the prospective students did not understand that the libraries were providing the service. We preferred to host the activities within our libraries so that students could meet other librarians and become familiar with the library space.

- Internal review board approval. Ideally, we would have liked to research what impact our libraries orientation activity had on student recruitment. For example, how many of the prospective students decided to enroll at UA? And, are the students that participated in the Sibling Orientation library activity more likely to use our library services compared to students who did not participate in the orientation? However, as the majority of prospective students were minors and their parents were not present during the activity, logistically it was not possible for us to easily obtain consent forms for data collection useful for research studies. We recommend working very closely with your admissions office and IRB team to determine if it is possible to obtain the proper consent forms for research.

\section{So what can you do?}

Our guess is that your library likely has many exciting services or programs that not many prospective students would associate with a library. For example, libraries are now starting to adopt new technology services and programs such as 3-D printing, Arduino/Raspberry Pi programming, gaming activities, and digital media production centers. Why not come up with an activity using these services rather than simply telling the prospective students how awesome these technologies are, or, perhaps worse, overwhelmingly them with information resources?

Importantly, new technology is not a prerequisite. You could use a good old computer and some software to help students design a postcard or website, graph data, create a map of the places they have visited, or maybe even create a word cloud (okay, maybe not a word cloud, those are a bit overdone). The point is, let's show prospective students that libraries are here to help them create, and that librarians are here to help. We can save the more traditional library instruction, such as databases, e-resource access, and other research skills, for later.

If students view libraries as a fun and exciting place, they may be more likely to seek our help when working on their own research. After all, isn't research simply an act of discovering and creating new knowledge?

(continues on page 91) 
budget to underwriting the actual publishing costs across the disciplines, without the huge discrepancies and price increases that plague the current market and keep research out of the public's hands.

\section{What issue(s) about open access} publishing in the social sciences do you think warrants immediate attention and action?

One issue I would identify is the role of the social science scholarly societies in open access. The societies now have to consider to what degree the journals must remain profit centers for running the society. They need to explore open access models that will better serve their membership and readers, including the larger community. Let us have that open discussion about what is the appropriate economic model for scholarly communication and the society's vital role in it.

4. What recommendations do you have for university presses and academic/research libraries to further the development of open access in the social sciences?

Following what I have written above, I can only recommend that presses and libraries explore alternative models of cooperative and collective action based on covering rigorously academic and professionally managed publishing costs. I have worked for well over a decade, and will continue to work with the dedicated team at PKP to provide one piece

\section{"Recruiting ..." (cont. from page 78)}

\section{Notes}

1. E. Lombard, "The role of the academic library in college choice," Journal of Academic Librarianship 38 (4):237-41.

2. K. M. Soria, "Factors predicting the importance of libraries and research activities for undergraduates," Journal of Academic Librarianship 39 (6):464-70.

3. M. D. Behr, M. Bundza, and B. J. Cockrell, "Going for the gold: Recruiting students and engaging administrators through education and entertainment in the library," College of this puzzle by producing the most technically sophisticated and elegant management and publishing platform we can. And we're not the only ones out there doing this. How strange it is to put free-market competitive pricing of publishing services at the forefront of a cooperative and universal model of open access to research and scholarship. We live in strange and interesting times for learning, with the potential, surely, for great things.

\section{Notes}

1. Pynchon and Philosophy (London: Palgrave Macmillan, 2014).

2. Open Access and the Humanities: http:// dx.doi.org/10.1017/CBO9781316161012.

3. Open Library of Humanities: https:// www.openlibhums.org.

4. arXiv: http://arxiv.org/.

5. Knowledge Unlatched: http://www. knowledgeunlatched.org/.

6. OAPEN-NL: http://www.oapen.nl /index.php?option $=$ com_content $\&$ view $=$ article $\&$ id $=58 \&$ Itemid $=63$.

7. OAPEN-UK: http://oapen-uk.jiscebooks.org/.

8. HEFCE Monographs project: http:// www.hefce.ac.uk/whatwedo/rsrch /rinfrastruct/oa/monographs/.

9. Public Knowledge Project: https://pkp. sfu.ca/.

10. Open Journal Systems: https://pkp. sfu.ca/ojs/.

11. Library Partnership Subsidies: https://www.openlibhums.org/2014/04/07 /library-partnership-subsidies-lps/. $\boldsymbol{n}$

4. M. A. Hubbard and A. T. Loos, "Academic library participation in recruitment and retention initiatives," Reference Services Review 41 (2):157-81.

5. L. Miller, "The library and the campus visit, Communicating value to prospective students and parents," College and Research Libraries News 73 (10):586-89.

6. M. G. Kopp, "Academic libraries, institutional missions, and new student recruitment: A case study," Reference Services Review 41 (2):192-200. $n$ 